\title{
Some coagulase-negative Staphylococcus species affect udder health more than others
}

\author{
K. Supré,${ }^{\star 1}$ F. Haesebrouck,† R. N. Zadoks,‡ M. Vaneechoutte,§ S. Piepers, ${ }^{\star}$ and S. De Vliegher \\ ${ }^{*}$ Department of Reproduction, Obstetrics, and Herd Health, and \\ †Department of Pathology, Bacteriology, and Avian Diseases, Faculty of Veterinary Medicine, Ghent University, Belgium \\ $\ddagger$ Royal (Dick) School of Veterinary Studies, University of Edinburgh, and Moredun Research Institute, Penicuik, Scotland \\ §Laboratory Bacteriology Research, Department of Clinical Chemistry, Microbiology, and Immunology, Faculty of Medicine, \\ Ghent University, Belgium
}

\section{ABSTRACT}

A longitudinal study in 3 dairy herds was conducted to profile the distribution of coagulase-negative Staphylococcus (CNS) species causing bovine intramammary infection (IMI) using molecular identification and to gain more insight in the pathogenic potential of CNS as a group and of the most prevalent species causing IMI. Monthly milk samples from 25 cows in each herd as well as samples from clinical mastitis were collected over a 13-mo period. Coagulase-negative staphylococci were identified to the species level using transfer-RNA intergenic spacer PCR. The distribution of CNS causing IMI was highly herd-dependent, but overall, Staphylococcus chromogenes, Staphylococcus xylosus, Staphylococcus cohnii, and Staphylococcus simulans were the most prevalent. No CNS species were found to cause clinical mastitis. The effect of the most prevalent species on the quarter milk somatic cell count (SCC) was analyzed using a linear mixed model, showing that Staph. chromogenes, Staph. simulans, and Staph. xylosus induced an increase in the SCC that is comparable with that of Staphylococcus aureus. Almost all CNS species were able to cause persistent IMI, with Staph. chromogenes causing the most persistent infections. In conclusion, accurate species identification cannot be ignored when studying the effect of CNS on udder health, as the effect on SCC differs between species and species distribution is herd-specific. Staphylococcus chromogenes, Staph. simulans, and Staph. xylosus seem to be the more important species and deserve special attention in further studies. Reasons for herd dependency and possible cow- and quarter-level risk factors should be examined in detail for the different species, eventually leading to cost-benefit analyses for management changes and, if needed, treatment recommendations.

Received August 19, 2010.

Accepted January 19, 2011.

${ }^{1}$ Corresponding author: Karlien.Supre@UGent.be
Key words: bovine intramammary infection, coagulase-negative Staphylococcus species, mastitis, somatic cell count

\section{INTRODUCTION}

As a group, CNS are the most prevalent bacteria found in bovine milk samples in many areas around the world (e.g., Tenhagen et al., 2006; Piepers et al., 2007; Schukken et al., 2009). They are cultured from milk from cows with and without elevated SCC and have been associated with mild clinical mastitis $(\mathbf{C M})$ cases (Waage et al., 1999; Thorberg et al., 2009). Also, they are abundantly present on teat apices and other body sites and in the cows' environment (Matos et al., 1991; De Vliegher et al., 2003; Taponen et al., 2008). Still, their clinical/pathogenic relevance when cultured from milk remains a point of discussion. Some consider them as true mastitis pathogens with important virulence factors (Zhang and Maddox, 2000), a high level of antimicrobial resistance (Rajala-Schultz et al., 2009), and the ability to cause chronic infections (Gillespie et al., 2009). Others regard them as minor pathogens (Schukken et al., 2009). On the other hand, they have as well been considered as potentially interesting microorganisms that can protect quarters against IMI with more harmful pathogens, either when causing IMI (Lam et al., 1997) or when colonizing bovine teats (De Vliegher et al., 2004). In some studies (Zadoks et al., 2001) or for some major pathogens (Lam et al., 1997), the presence of CNS was not protective against IMI with other species. An association between the presence of CNS and increased risk of mastitis with major pathogens has also been documented (Hogan et al., 1988).

Conflicting results on the importance of CNS can partly be attributed to identification issues. The CNS group consists of more than 50 different species and subspecies (www.bacterio.cict.fr/s/staphylococcus. html) with approximately a dozen commonly found in milk of dairy cows (Taponen et al., 2006; Gillespie et al., 2009; Sampimon et al., 2009a). New species causing 
IMI in dairy cows are still being described (Supré et al., 2010). Group-level identification of CNS has long been the standard, even for research purposes, and remains the default procedure in routine veterinary labs. However, it is reasonable to anticipate that some species are more important than others in relation to udder health. Only identification at the species level can help to clarify the relevance of different CNS species, but the quest for an accurate and low-cost technique has been a challenge for many years. Commercially available test kits on the basis of biochemical tests have been ruled out for this purpose as they lack accuracy (Sampimon et al., 2009b) and molecular identification is seen as the gold standard (Zadoks and Watts, 2009). At our laboratory, an inexpensive and accurate molecular test has been developed, facilitating the identification of a high number of CNS isolates, typically originating from field studies exploring the distribution and relevance of different CNS species (Supré et al., 2009).

The aims of this study were (1) to profile the distribution of CNS species causing IMI in 3 dairy herds using molecular identification, and (2) to gain more insight in the pathogenic potential of CNS as a group and of the most prevalent species associated with IMI. The relation between CNS and quarter milk SCC, and their ability to persist, was compared with Staphylococcus aureus and Corynebacterium bovis. In addition, the contribution of CNS to the incidence of $\mathrm{CM}$ was studied.

\section{MATERIALS AND METHODS}

\section{Herds}

Three commercial Flemish dairy farms, consisting of Black and Red Holstein-Friesians, were enrolled in the study. All participated in the local DHI program, with an average test-day interval of $35 \mathrm{~d}$ (range $27-44 \mathrm{~d}$ ). The herds had, on average, 53 lactating cows (range 39-70), and an average milk production at DHI test-day of 31.4 $\mathrm{kg} /$ cow per day (range 28.5-34.3 kg/d). The average 305 d milk yield was 10,099 $\mathrm{kg}$ (range 9,551-10,396 kg), and the average herd test-day SCC was 177,500 cells/ $\mathrm{mL}$ (range $98,000-323,000$ cells/mL) during the 13 -mo study period. Milking was performed in a $2 \times 5$ (farm 1 and 2 ) or a $2 \times 6$ (farm 3 ) haring bone milking parlor. A comparable milking technique was applied on all farms. Cows were milked twice daily by 2 milkers. On farm 2 , both milkers wore gloves during the milking process, whereas on the other farms, only 1 of the 2 did. The milking routine started with udder preparation using paper disposable towels, which were replaced after each cow, followed by pre-stripping of the teats. Automatic removal of the clusters was used in all herds. Teats were post-milking teat dipped or sprayed. Milking clusters were flushed with hot water $\left(>75^{\circ} \mathrm{C}\right)$ after cows with a high SCC or with a history of CM were milked. Blanket dry cow therapy, combined with an internal teat sealer, was applied on all cows, and the dry period lasted between 4 and 6 wk. Chronic (sub)clinical mastitis was considered a primary culling reason on farm 2 (based on the farmers opinion concerning chronicity), whereas on the other farms, cows with chronic (sub)clinical mastitis and no other symptoms were not removed from the herd. The udders were clipped several times a year. Cows were housed in freestall barns with cubicles (with sawdust bedding) and a concrete slatted floor. On farm 1 and 3, the slatted floors were manually cleaned twice per day, whereas on farm 2 this was not done routinely. Before parturition, cows were separated in a calving pen on straw. On 2 farms (1 and 3), sick cows were housed in this pen as well. The 10-point mastitis control program was to some extent already in place before the study started. Veterinary advice concerning udder health, which was based on the 10-point mastitis control program, was given to all farmers by the first author. This included monthly selection of cows with a high SCC, not part of the cohort of cows selected for study purposes (see below), for bacteriological milk culturing. The culture results were discussed with the farmer, and if deemed necessary, a suitable treatment was proposed using cow-level information such as stage of lactation, parity, number of quarters infected, SCC (for both cohort cows and others). However, quarters with a CNS infection were not treated, which fits with our general approach in extension work. The farmers were advised to take milk samples for bacteriological culturing of every clinical case (also from non-cohort cows). Results and treatment were discussed with the farmer for both cohort and non-cohort cows.

\section{Cows}

On each farm, a cohort of 25 animals was randomly selected within parity blocks (first, second, and third or more) at the onset of the study, using an Excel RAND function (Excel 2007; Microsoft Corp., Redmond, WA). The proportion of cows that was selected per parity reflected the parity distribution in the herd. When a cohort cow was sold or culled, another cow of the same parity and comparable lactation stage was added to the cohort. As 14 cows were replaced, a total of 89 cows contributed to the data sets over the course of the study. The median number of samplings a cow underwent, was 10 (range 2-12).

\section{Sampling and Data Recording}

Cohort Samples. The sampling period started in September 2007 and ended in January 2009. Sampling 
was conducted within 1 wk after receiving the DHI data for a total of 12 samplings per herd, during the evening milking. On each sampling day, 1 milk sample (approximately $25 \mathrm{~mL}$ ) was taken secundum artem, following the guidelines of the National Mastitis Council (Hogan et al., 1999) from each quarter of the cohort cows for standard bacteriological culturing and determination of SCC at the quarter level (qSCC). Parity, milk production, and DIM were available through the DHI data.

Additional Samples. Farmers were asked to collect milk samples aseptically (approximately $10 \mathrm{~mL}$ ) for bacteriological culturing at drying-off, when the cow was reintroduced into the lactating group after calving, and in the event of CM (defined as alterations in milk; e.g., presence of flakes, a swollen or painful quarter, and general symptoms).

\section{Laboratory Analyses}

Culture. Standard culturing of all milk samples was performed following the guidelines of the National Mastitis Council (Hogan et al., 1999). In short, a 0.01-mL loop of milk was spread on an esculin blood agar plate (Gibco Technologies, Paisley, Scotland) and incubated aerobically at $37^{\circ} \mathrm{C}$. Phenotypic features were examined after 24 and $48 \mathrm{~h}$ (morphology, gram staining, catalase test, esculin reaction, and DNase) to identify the pathogen as gram-negative bacteria, member of the Streptococcus-Enterococcus group (divided into esculinpositive or -negative), Staph. aureus, CNS, C. bovis, or another pathogen (e.g., yeast or Bacillus spp.). A milk sample was defined as contaminated if $>2$ different colony types were present. All CNS from clinical samples and CNS present with $\geq 500 \mathrm{cfu} / \mathrm{mL}$ from subclinical samples were inoculated on fresh agar plates and after another 18 - to 24 -h incubation at $37^{\circ} \mathrm{C}$, the cultures were checked for purity. Pure cultures were stored at $-80^{\circ} \mathrm{C}$ until further use.

Molecular Identification. The DNA of the selected CNS cultures (these are all CNS isolated from clinical samples and CNS present with $\geq 500 \mathrm{cfu} / \mathrm{mL}$ from subclinical samples) was prepared by alkaline extraction as described by Baele et al. (2000). Supernatants were either directly used as DNA extracts for transfer-RNA intergenic spacer PCR (tDNA-PCR) or stored at $-20^{\circ} \mathrm{C}$ until further use. The tDNA-PCR technique was performed using the methods and the library as described previously, and the rpoB housekeeping gene was sequenced if no identification could be obtained with tDNA-PCR (due to failure to produce a tDNA-PCR fingerprint or due to lack of a matching tDNA-PCR fingerprint in the tDNA-PCR library; Supré et al., 2009).
$\boldsymbol{S C C}$. Determination of the SCC was determined using a Fossomatic 5000/FC (Foss Electric, Hillerød, Denmark).

\section{Definition of IMI}

A quarter was defined as having a subclinical IMI with a specific bacterium at the cohort sampling day when the current sample contained $\geq 1,000 \mathrm{cfu} / \mathrm{mL}$, or $\geq 500 \mathrm{cfu} / \mathrm{mL}$ for that specific bacterium in at least 2 out of 3 consecutive samplings (previous, current, or next sample) in the absence of clinical signs. The same definition was used to assign an IMI status to the first and last sampling for each cow, although in these cases no previous or next sample, respectively, was available. The IMI status of the first sampling could only be determined when (1) the first sampling contained $\geq 1,000$ $\mathrm{cfu} / \mathrm{mL}$, or (2) the first and second sampling contained $\geq 500 \mathrm{cfu} / \mathrm{mL}$. In all other cases, the IMI status of the first sample remained unknown. Similarly, the IMI status of the last sampling could only be determined when (1) the last sampling contained $\geq 1,000 \mathrm{cfu} / \mathrm{mL}$, or (2) the last and next-to-last sampling contained $\geq 500 \mathrm{cfu} /$ $\mathrm{mL}$. In all other cases, the IMI status of the last sample remained unknown. A quarter sampled at dry-off or calving was considered to have an IMI if $\geq 1,000 \mathrm{cfu} /$ $\mathrm{mL}$ of a bacterium were present. A clinical IMI was defined as coming from a quarter with clinical signs from which $\geq 100 \mathrm{cfu} / \mathrm{mL}$ of Staph. aureus, members of the Streptococcus-Enterococcus group, or gram-negative bacteria, or $\geq 500 \mathrm{cfu} / \mathrm{mL}$ of $C$. bovis, CNS, or Bacillus species were isolated. A quarter was allowed to have an IMI with 2 different bacteria at the same moment, and these were accounted for as 2 different IMI.

Using the aforementioned definitions, transient and persistent IMI caused by Staph. aureus, C. bovis, and the different CNS species were studied. A quarter was considered as having a transient IMI when it had an IMI with a staphylococcal species or $C$. bovis that was absent at the previous and the next sampling, and a persistent IMI when a quarter had an IMI at $\geq 2$ consecutive samplings caused by the same staphylococcal species or $C$. bovis. The duration of persistent IMI was computed as follows. When a quarter was infected at calving, the day of calving was considered to be the starting point of infection, unless the IMI had also been detected at dry-off. In that case, the infection was considered to have persisted during the dry period. When IMI occurred during lactation in the course of the study period, the infection was assumed to have started halfway between the last and current sampling. When the cow was infected when entering or leaving the study, an extra period of time was added to the calculation 
[i.e., the average number of days between 2 samplings (for that herd), divided by 2]. The endpoint of infection was considered to be the midpoint between the current sampling with IMI and the next sampling without IMI, or the dry-off date when the quarter was infected at dry-off (and noninfected at calving).

\section{Descriptive Data Analysis}

The herd-specific distribution of all pathogens causing subclinical and CM over the course of the study were described. The incidence rate of CM per cow-month at risk for all pathogens was computed excluding the drycow period. For each case of CM, $14 \mathrm{~d}$ were subtracted from the days at risk (Barkema et al., 1998) and a new clinical case in the same quarter could appear after a 14-d period since the first case. The persistence and cure during the dry period, and the occurrence of new IMI across the dry period were determined for all pathogens.

For the different staphylococcal species and C. bovis, the number of transient and persistent IMI, as well as the length of the persistent IMI, was described.

\section{Statistical Analyses}

The effects on qSCC of IMI caused by CNS as a group, and the effect on qSCC of IMI caused by the most prevalent CNS species, respectively, were studied.

Thus, first, qSCC of CNS-infected quarters were compared with qSCC of noninfected quarters and with qSCC from quarters infected with Staph. aureus or $C$. bovis (model 1). This was achieved by fitting a linear mixed model with the natural log-transformed qSCC (lnqSCC) as outcome variable and IMI status as independent variable of main interest (noninfected, Staph. aureus IMI, C. bovis IMI, IMI caused by all CNS as one group, and a group with all other IMI statuses combined).

Second, qSCC of quarters infected with the most prevalent CNS species individually, Staph. aureus, and C. bovis were compared (model 2). This was achieved by fitting a linear mixed model with lnqSCC as outcome variable and IMI status as independent variable of main interest (noninfected, Staph. aureus IMI, C. bovis IMI, IMI caused by CNS other than listed, Staphylococcus chromogenes IMI, Staphylococcus cohnii IMI, Staphylococcus simulans IMI, Staphylococcus xylosus IMI, and all other IMI statuses combined). The group in which all other IMI statuses were combined contained IMI with gram-negative bacteria, streptococci-enterococci, Bacillus spp., and yeasts, as well as quarters with a double IMI, and the contaminated samples.
Third, the effect of persistency status of IMI on the lnqSCC was investigated. This was achieved by fitting a linear mixed model with lnqSCC as outcome variable and IMI status (Staph. aureus IMI, C. bovis IMI, IMI caused by Staph. chromogenes, Staph. cohnii, and Staph. simulans as a group, and IMI by all other CNS as a group, respectively), persistency status (persistent IMI versus transient IMI), and the interaction term between both as variables of main interest (model 3).

Clustering of the data (repeated observations over time within quarters, and quarters within cows) was taken into account by adding quarter and cow as random effects, respectively. An autoregressive-1 correlation structure was used to model the repeated measurements. Herd was forced in all models as fixed effect. At the observation level, the variables DIM (continuous), DIM $\times$ DIM, parity (1, first parity; 2, second parity; $3, \geq 3$ parity), and test-day milk production (continuous) were considered. Quarter position (1, front; 2 , hind quarter) was tested as a quarter-level fixed effect.

Analyses were run with SAS 9.21 (SAS System for Windows, SAS Institute Inc., Cary, NC) using the PROC-MIXED procedure. A multistep approach was applied. Predictor variables that were significant $(P \leq$ $0.15)$ in the univariable models were combined in a multivariable model in which nonsignificant variables were removed at $P \leq 0.05$ using a backward stepwise approach. The 3 final models for lnqSCC contained DIM, parity, milk production and IMI status as significant predictor values. A Bonferroni correction was applied to adjust for multiple comparisons when comparing the effect of different IMI on lnqSCC.

\section{RESULTS}

\section{Description of the Cohort Data}

During the 13-mo study period, 3,064 cohort quarter milk samples were collected from 89 cows (Table 1). Eleven samples were not cultured $(0.4 \%)$ precluding assignment of an IMI status to these samples. The IMI status for another 153 quarter samples (5.0\%) remained unknown because of the definitions used, and 220 milk samples were considered contaminated (7.2\%). An IMI status was assigned to 2,680 quarter samples, of which $2,015(75.2 \%)$ were noninfected and 665 had an IMI (24.8\%). In 28 of the 665 IMI-positive samples, 2 different IMI were present. This resulted in 693 IMI determined throughout the entire study period, in total (Table 1).

\section{Distribution of All Mastitis Pathogens Causing Subclinical IMI}

Corynebacterium bovis was the predominant pathogen causing IMI (55.3\% of all IMI; $51.9,58.2$, and $55.3 \%$ in 
herds 1 to 3 , respectively; Table 1 ). Coagulase-negative staphylococci were the second most prevalent bacteria (25.8\% of all IMI; $36.2,28.0$, and $10.7 \%$ in herds 1 to 3 , respectively), whereas Staph. aureus caused $6.9 \%$ of all IMI $(1.7,1.9$, and $19.8 \%$ in herds 1 to 3 , respectively). Twelve percent of the IMI were caused by other pathogens (6.2\% esculin-positive members of the Streptococcus-Enterococcus group; 3.5\% Bacillus spp., yeasts, and unidentified bacteria; $1.9 \%$ gram-negative bacteria; and $0.4 \%$ esculin-negative members of the Streptococcus-Enterococcus group).

\section{Distribution of CNS Species Causing Subclinical IMI}

Overall, IMI caused by 12 different CNS species were identified (Table 1). Two single CNS isolates causing IMI remained unidentified. Five quarter samples were infected with 2 different CNS species. Staphylococcus chromogenes was the predominant species, causing $46.4 \%$ of all CNS IMI, although its contribution differed considerably between farms. Other species causing IMI were (in decreasing prevalence) Staph. xylosus, Staph. cohnii, Staph. simulans, Staphylococcus hemolyticus, Staphylococcus fleurettii, Staphylococcus devriesei, Staphylococcus sciuri, Staphylococcus epidermidis, Staphylococcus equorum, Staphylococcus hyicus, and Staphylococcus pasteuri. Distributions of CNS IMI were herd-specific (Table 1). In herd 2, Staph. xylosus was the most prevalent species, whereas it was not involved in IMI in the other herds. Similar herd-specificity was seen for Staph. cohnii (second most IMI-causing species in herd 1 but absent from the other herds) and Staph. simulans (frequently found in herd 2 but absent and almost absent from herds 3 and 1, respectively). Also, more different CNS species were found in herd 1 than in herds 2 and 3.

\section{Incidence of Clinical Mastitis and Causative Pathogens}

During the study, $31 \mathrm{CM}$ cases were detected in 27 quarters of 21 cows ( 8 in herd 1, 14 in herd 2, and 9 in herd 3$)$. The incidence rate per cow-month at risk was 0.041 for all herds $(0.034,0.052$, and 0.035 for herds 1 to 3, respectively). Gram-negative bacteria caused most cases of CM (9 cases), followed by Staph. aureus and esculin-positive members of the Streptococcus-Enterococcus group (4 cases each). Corynebacterium bovis was cultured from $1 \mathrm{CM}$ case. No CNS species were found to cause CM cases. The remainder of cases were considered noninfected according to the definitions used ( $\mathrm{n}=$ 11 ), or consisted of contaminated samples $(n=2)$.

\section{Pathogens Associated with IMI at Dry-Off and Parturition}

Sixty cows completed their dry period during the study. Of the 240 quarters, $165(68.8 \%)$ were noninfected at both drying-off and parturition. Thirty-five quarters $(14.6 \%)$ had an IMI with any pathogen at drying-off that cured across the dry period, and 14 new IMI were present at calving. For 24 quarters, the IMI status at either drying-off or at calving, or both, was undefined. The majority of the new infections at calving was caused by CNS (64.3\%), whereas none and $7.1 \%$ of the new IMI were caused by Staph. aureus and C. bovis, respectively. The only IMI that did not cure during the dry period was caused by Staph. chromogenes (in 2 quarters).

\section{Transient Versus Persistent CNS IMI}

Thirty-seven transient and 30 persistent CNS IMI were detected. Of 14 CNS IMI, the persistency status was unknown, mostly because of their occurrence at the beginning or end of the study (left- or right-censoring, respectively), making it impossible to decide whether they were persistent or transient. Staphylococcus chromogenes caused more persistent than transient IMI, and Staph. xylosus was slightly more involved in persistent compared with transient IMI. Staphylococcus cohnii, Staph. hemolyticus, and Staph. simulans caused more transient than persistent IMI, and Staph. fleurettii only caused transient IMI (Table 2). Cows in herd 1 were more likely to have persistent Staph. chromogenes IMI compared with cows in the other herds, because in herd 1 , there were 11 persistent IMI and only 1 transient IMI, whereas this ratio was $3 / 3$ in herd 2 and $2 / 3$ in herd 3 , respectively. Staphylococcus aureus caused as much transient as persistent IMI, whereas $C$. bovis caused almost twice as much persistent as transient IMI. Infections with Staph. aureus lasted, on average, 199 d, which is more than Staph. simulans, Staph. xylosus, Staph. chromogenes, C. bovis, Staph. devriesei, Staph. cohnii, and Staph. hemolyticus, respectively (Table 2).

\section{Association Between CNS IMI and Quarter Milk SCC}

The geometric mean qSCC $(\times 1,000$ cells $/ \mathrm{mL})$ and the 25 th to 75 th percentiles were 26.8 (10-61) for noninfected quarters, 494.9 (310-1,007) for Staph. aureus IMI, 87.7 (39-171.8) for C. bovis IMI, and 137.0 (74-298) for CNS as a group. When the CNS were considered as separate species, the geometric mean qSCC $(\times 1,000$ cells $/ \mathrm{mL}$ ) and the 25 th to 75 th percentiles were 225.7 
Table 1. Overview of the data set and distribution of CNS causing IMI (as defined in the text) throughout a 13-mo study period, from 3 dairy herds

\begin{tabular}{|c|c|c|c|c|c|c|c|c|c|c|c|c|c|c|c|c|}
\hline \multirow[b]{2}{*}{ Item } & \multicolumn{4}{|c|}{ Herd 1} & \multicolumn{4}{|c|}{ Herd 2} & \multicolumn{4}{|c|}{ Herd 3} & \multicolumn{4}{|c|}{ Total } \\
\hline & $\mathrm{n}$ & $\begin{array}{c}\text { Samples } \\
(\%)\end{array}$ & $\begin{array}{l}\text { IMI } \\
(\%)\end{array}$ & $\begin{array}{c}\text { CNS } \\
\text { IMI }(\%)\end{array}$ & $\mathrm{n}$ & $\begin{array}{c}\text { Samples } \\
(\%)\end{array}$ & $\begin{array}{l}\text { IMI } \\
(\%)\end{array}$ & $\begin{array}{c}\text { CNS } \\
\text { IMI }(\%)\end{array}$ & $\mathrm{n}$ & $\begin{array}{c}\text { Samples } \\
(\%)\end{array}$ & $\begin{array}{l}\text { IMI } \\
(\%)\end{array}$ & $\begin{array}{c}\text { CNS } \\
\text { IMI }(\%)\end{array}$ & $\mathrm{n}$ & Samples & $\begin{array}{l}\text { IMI } \\
(\%)\end{array}$ & $\begin{array}{c}\text { CNS } \\
\text { IMI }(\%)\end{array}$ \\
\hline Cows & 31 & & & & 28 & & & & 30 & & & & 89 & & & \\
\hline Quarter samples & 1,032 & & & & 1,036 & & & & 996 & & & & 3,064 & & & \\
\hline Noninfected quarter samples ${ }^{1}$ & 691 & 67.0 & & & 659 & 63.6 & & & 665 & 66.8 & & & 2,015 & 65.8 & & \\
\hline Status unknown/contaminated & 117 & 11.3 & & & 126 & 12.2 & & & 141 & 14.2 & & & 384 & 12.5 & & \\
\hline Infected quarter samples ${ }^{1}$ & 224 & 21.7 & & & 251 & 24.2 & & & 190 & 19.1 & & & 665 & 21.7 & & \\
\hline IMI by ${ }^{2}$ to & 235 & 22.8 & & & 261 & 25.2 & & & 197 & 19.8 & & & 693 & 22.6 & & \\
\hline Staphylococcus aureus & 4 & 0.4 & 1.7 & & 5 & 0.5 & 1.9 & & 39 & 3.9 & 19.8 & & 48 & 1.6 & 6.9 & \\
\hline Corynebacterium bovis & 122 & 11.8 & 51.9 & & 152 & 14.7 & 58.2 & & 109 & 10.9 & 55.3 & & 383 & 12.5 & 55.3 & \\
\hline CNS & 85 & 8.2 & 36.2 & & 73 & 7.0 & 28.0 & & 21 & 2.1 & 10.7 & & 179 & 5.8 & 25.8 & \\
\hline Staphylococcus chromogenes & 52 & 5.0 & 22.1 & 61.2 & 17 & 1.6 & 6.5 & 23.3 & 14 & 1.4 & 7.1 & 66.7 & 83 & 2.7 & 12.0 & 46.4 \\
\hline Staphylococcus xylosus & 0 & & & & 28 & 2.7 & 10.7 & 38.4 & 0 & & & & 28 & 0.9 & 4.0 & 15.6 \\
\hline Staphylococcus cohnii & 20 & 1.9 & 8.5 & 23.5 & 0 & & & & 0 & & & & 20 & 0.7 & 2.9 & 11.2 \\
\hline Staphylococcus simulans & 2 & 0.2 & 0.9 & 2.4 & 15 & 1.4 & 5.7 & 20.5 & 0 & & & & 17 & 0.6 & 2.5 & 9.5 \\
\hline Staphylococcus hemolyticus & 3 & 0.3 & 1.3 & 3.5 & 5 & 0.5 & 1.9 & 6.8 & 3 & 0.3 & 1.5 & 14.3 & 11 & 0.4 & 1.6 & 6.1 \\
\hline Staphylococcus fleurettii & 1 & 0.1 & 0.4 & 1.2 & 5 & 0.5 & 1.9 & 6.8 & 0 & & & & 6 & 0.2 & 0.9 & 3.4 \\
\hline Staphylococcus devriesei & 3 & 0.3 & 1.3 & 3.5 & 1 & 0.1 & 0.4 & 1.4 & 1 & 0.1 & 0.5 & 4.8 & 5 & 0.2 & 0.7 & 2.8 \\
\hline Staphylococcus sciuri & 1 & 0.1 & 0.4 & 1.2 & 1 & 0.1 & 0.4 & 1.4 & 1 & 0.1 & 0.5 & 4.8 & 3 & 0.1 & 0.4 & 1.7 \\
\hline Staphylococcus epidermidis & 1 & 0.1 & 0.4 & 1.2 & 0 & & & & 0 & & & & 1 & $<0.1$ & 0.1 & 0.6 \\
\hline Staphylococcus equorum & 0 & & & & 0 & & & & 1 & 0.1 & 0.5 & 4.8 & 1 & $<0.1$ & 0.1 & 0.6 \\
\hline Staphylococcus hyicus & 0 & & & & 1 & 0.1 & 0.4 & 1.4 & 0 & & & & 1 & $<0.1$ & 0.1 & 0.6 \\
\hline Staphylococcus pasteuri & 1 & 0.1 & 0.4 & 1.2 & 0 & & & & 0 & & & & 1 & $<0.1$ & 0.1 & 0.6 \\
\hline Unidentified CNS & 1 & 0.1 & 0.4 & 1.2 & 0 & & & & 1 & 0.1 & 0.5 & 4.8 & 2 & 0.1 & 0.3 & 1.1 \\
\hline Other pathogens ${ }^{3}$ & 24 & 2.3 & 10.2 & & 31 & 3.0 & 11.9 & & 28 & 2.8 & 14.2 & & 83 & 2.7 & 12.0 & \\
\hline
\end{tabular}

${ }^{1}$ Noninfected/infected quarter samples refers to absence or presence of IMI, respectively, based on bacterial growth, number of cfu/mL, and consecutive samplings. A quarter was defined as having a subclinical IMI with a specific bacterium when the current sample contained $>1,000 \mathrm{cfu} / \mathrm{mL}$, or $>500 \mathrm{cfu} / \mathrm{mL}$ for that specific bacterium in at least 2 out of 3 consecutive samplings (previous, current, or next sample) in the absence of clinical signs. A clinical IMI was defined as coming from a quarter with clinical signs from which $>100$ $\mathrm{cfu} / \mathrm{mL}$ of Staph. aureus, members of the Streptococcus-Enterococcus group, or gram-negative bacteria, or $\geq 500 \mathrm{cfu} / \mathrm{mL}$ of $C$. bovis, CNS, or Bacillus species were isolated.

${ }^{2}$ Inconsistencies between number of infected quarters and number of IMI is due to multiple pathogens causing IMI in the same quarter.

${ }^{3}$ Gram-negative bacteria, Streptococcus-Enterococcus group, Bacillus species, and yeasts. 
Table 2. Overview of the persistency status of IMI in quarters infected with Staphylococcus aureus, Corynebacterium bovis, and the most prevalent CNS over all herds during the 13-mo study period

\begin{tabular}{|c|c|c|c|c|c|c|}
\hline Species & $\begin{array}{l}\text { Cows }^{1} \\
\text { (n) }\end{array}$ & $\begin{array}{l}\text { Quarters }^{2} \\
(\mathrm{n})\end{array}$ & \multicolumn{3}{|c|}{ Persistency status } & $\begin{array}{l}\text { Mean duration } \\
\text { and range of } \\
\text { persistent IMI (d) }\end{array}$ \\
\hline Staph. aureus & 16 & 21 & 6 & 6 & 10 & $198.9(88.5-330)$ \\
\hline Staphylococcus chromogenes & 16 & 30 & 7 & 16 & 9 & $147.8(89-303)$ \\
\hline Staphylococcus cohnii & 11 & 12 & 7 & 4 & 1 & $92.3(66.5-144)$ \\
\hline Staphylococcus devriesei & 3 & 3 & 2 & 1 & 0 & $97(-)$ \\
\hline Staphylococcus simulans & 5 & 8 & 5 & 2 & 1 & $176(140-212)$ \\
\hline Staphylococcus xylosus & 9 & 11 & 3 & 5 & 3 & $151.9(78.5-184.5)$ \\
\hline
\end{tabular}

${ }^{1}$ During the study, a cow could contribute multiple times to this column.

${ }^{2}$ During the study, a quarter could contribute multiple times to this column.

${ }^{3}$ Transient IMI, defined as IMI with a pathogen that was absent at the previous and the next sampling.

${ }^{4}$ Persistent IMI, defined as an IMI with the same pathogen at $\geq 2$ consecutive samplings.

${ }^{5}$ Unknown persistency status.

(103-463) for Staph. chromogenes IMI, 65.1 (37-160) for Staph. cohnii IMI, 130.0 (104.5-245.3) for Staph. simulans IMI, 84.6 (48-197.5) for Staph. xylosus IMI, and $69.2(23.5-148.5)$ for IMI with the remaining CNS species.

In model 1, all infected quarters showed a higher lnqSCC than the noninfected quarters, regardless of the causative pathogen $(P<0.001)$. Quarters with a CNS IMI had a higher lnqSCC than did quarters infected with $C$. bovis $(P<0.001)$, but lower than $S$. aureusinfected quarters $(P<0.01$; Tables 3 and 4$)$.

Model 2 showed that the lnqSCC did not differ significantly between noninfected quarters and quarters with a Staph. cohnii IMI. No significant difference was found between the lnqSCC of the individual CNS species and the other CNS group. Quarters with Staph. chromogenes and Staph. simulans IMI had a higher lnqSCC than did quarters infected with $C$. bovis $(P$ $<0.01$ ). The lnqSCC of quarters infected with Staph. chromogenes, Staph. simulans, or Staph. xylosus was not different from the lnqSCC from Staph. aureus-infected quarters $(P>0.05$; Tables 3 and 4$)$.

The interaction term between persistency and IMI status was not significant in model $3(P=0.09)$, nor was persistency $(P=0.13)$ in a model without the interaction term present.

\section{DISCUSSION}

In this detailed longitudinal field study using molecular identification of CNS, the distribution of different CNS species causing IMI and their species-specific effect on udder health was scrutinized. Distribution of CNS species causing IMI was herd-dependent. Some species such as Staph. chromogenes, Staph. simulans, and Staph. xylosus, caused an inflammatory response, as measured by the SCC, which was not different from the one caused by Staph. aureus, whereas the other CNS species did not. All CNS species, except Staph. fleurettii, were able to cause persistent IMI, whereas this was most pronounced for Staph. chromogenes. Remarkably, this was true for $C$. bovis as well. None of the clinical mastitis cases were caused by CNS.

In our study, the majority of IMI was not caused by CNS but by $C$. bovis, which is in contrast to findings from previous studies (Rajala-Schultz et al., 2004; Piepers et al., 2007; Schukken et al., 2009). It reflects that many factors influence the observed distribution of pathogens associated with mastitis under different management styles. Staphylococcus chromogenes, followed by Staph. xylosus, Staph. cohnii, Staph. simulans, and Staph. hemolyticus, were accountable for the majority of quarter samples with a CNS IMI. Comparison with earlier studies can be hindered by the plethora of identification tests, IMI definitions, and the different inclusion criteria for the selection of herds and cows, used in different studies. We made use of tDNA-PCR, which has a high accuracy for identifying bovine CNS, is low-cost, and easy to use (Supré et al., 2009), rendering it a useful tool in elaborate field studies. We applied a restrictive and strict IMI definition. For the cohort samples, the IMI status was based on the number of $\mathrm{cfu} / \mathrm{mL}$ and 3 consecutive samplings. To our knowledge, only Taponen et al. (2007) used a similar design on 1 farm with a similar IMI definition for CNS, revealing Staph. chromogenes, Staph. simulans, and Staph. hemolyticus as the most prevalent CNS causing IMI. Other molecular-based studies on 1 (Rajala-Schultz et al., 2009) and 23 farms (Santos et al., 2008), but with different IMI definitions, confirmed that the same CNS 
Table 3. Final linear mixed regression models describing the natural log-transformed quarter milk SCC (lnqSCC) of CNS-infected quarters (as a group in model 1, and stratified for the most prevalent CNS species in model 2) compared with noninfected quarters and quarters infected with Staphylococcus aureus and Corynebacterium bovis, respectively

\begin{tabular}{|c|c|c|c|c|c|c|}
\hline \multirow[b]{2}{*}{ Item } & \multicolumn{3}{|c|}{ Model 1} & \multicolumn{3}{|c|}{ Model 2} \\
\hline & $\beta^{1}$ & $\mathrm{SE}$ & $P$-value & $\beta$ & $\mathrm{SE}$ & $P$-value \\
\hline Intercept & 4.906 & 0.243 & & 4.906 & 0.243 & \\
\hline DIM & 0.002 & 0.000 & $<0.001$ & 0.002 & 0.000 & $<0.001$ \\
\hline Herd $^{2}$ & & & 0.819 & & & 0.860 \\
\hline 1 & -0.022 & 0.170 & & -0.024 & 0.170 & \\
\hline 2 & 0.081 & 0.171 & & 0.067 & 0.171 & \\
\hline 3 & Reference & - & & Reference & - & \\
\hline Parity & & & $<0.001$ & & & $<0.001$ \\
\hline 1 & -0.976 & 0.145 & & -1.006 & 0.145 & \\
\hline 2 & -0.504 & 0.103 & & -0.496 & 0.102 & \\
\hline $3+$ & Reference & - & & Reference & - & \\
\hline Milk production (kg/d) & -0.045 & 0.005 & $<0.001$ & -0.045 & 0.005 & $<0.001$ \\
\hline IMI by & & & $<0.001$ & & & $<0.001$ \\
\hline Noninfected & Reference & - & & Reference & - & \\
\hline Staph. aureus & 2.026 & 0.222 & & 2.038 & 0.222 & \\
\hline C. bovis & 0.470 & 0.075 & & 0.468 & 0.075 & \\
\hline CNS group $^{3}$ & 1.151 & 0.123 & & 0.788 & 0.245 & \\
\hline Staphylococcus chromogenes & $\mathrm{ND}^{4}$ & ND & & 1.433 & 0.192 & \\
\hline Staphylococcus cohnii & ND & ND & & 0.661 & 0.337 & \\
\hline Staphylococcus simulans & ND & ND & & 1.864 & 0.369 & \\
\hline Staphylococcus xylosus & ND & ND & & 1.048 & 0.262 & \\
\hline Other $^{5}$ & 0.504 & 0.068 & & 0.500 & 0.068 & \\
\hline
\end{tabular}

${ }^{1}$ Regression coeeficient.

${ }^{2}$ Forced into the model.

${ }^{3}$ Model 1: all CNS combined as one group; model 2: other CNS than listed combined.

Not determined.

${ }^{5}$ IMI with gram-negative bacteria, Streptococcus-Enterococcus group, Bacillus species, and yeasts, as well as double IMI and contaminated samples.

species, but also Staph. epidermidis, Staphylococcus warneri, and Staph. xylosus frequently cause IMI. The large herd dependency of the CNS species distribution as mentioned in literature (Gillespie et al., 2009; Sampimon et al., 2009a; Thorberg et al., 2009) was supported by our results; however, other aspects might explain these differences. The discussion on CNS relevance that has been ongoing for many years might be due to the large species distribution in different herds and studies. This indicates the need for more detailed studies over many management systems and countries, but furthermore, might indicate the need for herd-specific management programs to control the important CNS species.

None of the CM cases could be assigned to CNS and only 1 to $C$. bovis, showing that their pathogenic potential is limited. Other authors did find CNS in (mild) clinical samples (Waage et al., 1999; Taponen et al., 2006; Gillespie et al., 2009) but whether or not CNS were causal in all cases remains a point of discussion. The relation between SCC and CNS IMI was studied in a detailed manner. The hierarchical structure of the longitudinal data was taken into account when estimating the relation between CNS IMI and the qSCC. Po- tential host (immunity) differences were corrected for by including a random cow effect and different cow-level fixed effects such as test-day milk yield and parity. The moderate $\mathrm{SCC}$ increase induced by $\mathrm{CNS}$ as a group (i.e., to a level intermediate between the SCC observed for noninfected quarters and $S$. aureus-infected quarters) was a confirmation of their status as minor pathogens (Taponen et al., 2007; Gillespie et al. 2009; Schukken et al., 2009; Sampimon et al., 2010). The SCC associated with CNS IMI was also higher than the SCC associated with infections due to $C$. bovis, confirming the results of others such as Sampimon et al. (2010). In addition, a specific merit of our study was to examine whether differences exist between the most prevalent CNS species. Staphylococcus chromogenes, Staph. simulans, and Staph. xylosus had a larger effect on qSCC than other species such as Staph. cohnii, and an effect that is comparable to that of Staph. aureus infections. This is different from what is mentioned in other studies in which no significant differences in qSCC between different CNS species has been described (Chaffer et al., 1999; Taponen et al., 2006; Thorberg et al., 2009). Recent in vivo work examined the internalization and adhesive capacity of some bovine CNS species and Staph. aureus 
Table 4. Differences of least squares means of the natural log-transformed quarter milk SCC (lnqSCC) between the different IMI statuses (Bonferroni-corrected $P$-values), based on the final linear mixed regression models describing the lnqSCC of CNS-infected quarters (as one group in model 1, and stratified for the most prevalent CNS species in model 2) compared with noninfected quarters and quarters infected with Staphylococcus aureus and Corynebacterium bovis, respectively

\begin{tabular}{|c|c|c|c|c|c|c|c|c|}
\hline \multirow[b]{2}{*}{ Item } & \multicolumn{8}{|c|}{ Reference } \\
\hline & Noninfected & $\begin{array}{l}\text { Staph. } \\
\text { aureus }\end{array}$ & C. bovis & $\begin{array}{l}\text { CNS } \\
\text { group }^{2}\end{array}$ & $\begin{array}{l}\text { Staphylococcus } \\
\text { chromogenes }\end{array}$ & $\begin{array}{c}\text { Staphylococcus } \\
\text { cohnii }\end{array}$ & $\begin{array}{c}\text { Staphylococcus } \\
\text { simulans }\end{array}$ & $\begin{array}{c}\text { Staphylococcus } \\
\text { xylosus }\end{array}$ \\
\hline \multicolumn{9}{|l|}{ Model 1} \\
\hline Noninfected & - & & & & & & & \\
\hline Staph. aureus & $2.026^{* * *}$ & - & & & & & & \\
\hline C. bovis & $0.470^{* * *}$ & $-1.556^{* * *}$ & - & & & & & \\
\hline CNS group $^{2}$ & $1.151^{* * *}$ & $-0.875^{* *}$ & $0.681^{* * *}$ & - & - & - & - & - \\
\hline Other $^{3}$ & $0.504^{* * *}$ & $-1.522^{* * *}$ & $0.034^{\mathrm{NS}}$ & $-0.647^{* * *}$ & - & - & - & - \\
\hline \multicolumn{9}{|l|}{ Model 2} \\
\hline Noninfected & - & & & & & & & \\
\hline Staph. aureus & $2.038^{* * *}$ & - & & & & & & \\
\hline C. bovis & $0.468^{* * *}$ & $-1.570^{* * *}$ & - & & & & & \\
\hline CNS group ${ }^{2}$ & $0.788^{*}$ & $-1.249^{* *}$ & $0.320^{\mathrm{NS}}$ & - & & & & \\
\hline Staphylococcus chromogenes & $1.433^{* * *}$ & $-0.605^{\mathrm{NS}}$ & $0.965^{* * *}$ & $0.644^{\mathrm{NS}}$ & - & & & \\
\hline Staphylococcus cohnii & $0.661^{\mathrm{NS}}$ & $-1.376^{*}$ & $0.19^{\mathrm{NS}}$ & $-0.127^{\mathrm{NS}}$ & $-0.771^{\mathrm{NS}}$ & - & & \\
\hline Staphylococcus simulans & $1.864^{* * *}$ & $-0.174^{\mathrm{NS}}$ & $1.396^{* *}$ & $1.076^{\mathrm{NS}}$ & $0.432^{\mathrm{NS}}$ & $1.203^{\mathrm{NS}}$ & - & \\
\hline Staphylococcus xylosus & $1.048^{* *}$ & $-0.990^{\mathrm{NS}}$ & $0.580^{\mathrm{NS}}$ & $0.260^{\mathrm{NS}}$ & $0.384^{\mathrm{NS}}$ & $0.387^{\mathrm{NS}}$ & $-0.816^{\mathrm{NS}}$ & - \\
\hline
\end{tabular}

${ }^{1}$ Both models contained DIM, parity, and IMI status as significant predictor variables.

ᄃ ${ }^{2}$ CNS-group in model 2 = CNS other than listed.

${ }^{3}$ IMI with gram-negative bacteria, Streptococcus-Enterococcus group, Bacillus species, and yeasts, as well as quarters with double IMI and contaminated samples.

$* P<0.05 ;{ }^{* *} P<0.01 ; * * P<0.001$. 
(Hyvönen et al., 2009). The adhesive capacity of Staph. chromogenes, Staph. cohnii, Staph. hemolyticus, and Staph. simulans was equal to that of Staph. Aureus, but their invasivity of mammary gland cells was weaker. A cytotoxic protease that induced neutrophil infiltration has been described for Staph. chromogenes (Zhang and Maddox, 2000), showing that at least this species holds important virulence factors potentially stimulating local immunity. Coagulase-negative staphylococci can harbor virulence factors that are also present in Staph. aureus strains (Kuroishi et al., 2003). As for Staph. aureus, the distribution of virulence factors may differ between strains within species (Lipman et al., 1996; Smith et al., 1998). Still, as no CNS caused CM in our study, we conclude that their virulence is more limited compared with the true major mastitis pathogens. In our opinion, the observed CM incidence rates reflect a fair representation of the actual number of cases occurring in these herds, limiting the potential underestimation of CNS as a true cause of CM.

Still, one could argue that the fact that no difference was detected in qSCC between Staph. aureus IMI and IMI caused by Staph. chromogenes, Staph. simulans, and Staph. xylosus was due to treatment effects. Indeed, antimicrobial treatment of Staph. aureus IMI could result in cure of the infection (in this way decreasing persistency effects) or might lower the qSCC of the particular quarter. However, although allowed for, none of the cohort cows was treated for subclinical mastitis caused by Staph. aureus $(\mathrm{n}=48)$ during the entire study period. Of the clinical Staph. aureus cases ( $\mathrm{n}=$ 4), 1 remained present in the quarter after treatment in subclinical form. It is possible that the treatment decreased the qSCC of this quarter, but we believe this will not have resulted in a serious underestimation of the average qSCC of all quarters with Staph. aureus IMI. Therefore, we feel confident that the qSCC did truly not differ between the 3 important CNS species and Staph. aureus.

The potential of CNS species to cause persistent infections was used as another parameter to estimate their virulence. In fact, almost all CNS species were able to cause persistent IMI, and in particular, Staph. chromogenes caused more persistent than transient IMI. This was consistent with the work of Taponen et al. (2007), although they found that the persistency of Staph. chromogenes was not different from other CNS species and concluded that host-microbe interaction plays a key role. This was also supported by Gillespie et al. (2009). In our study, both the potential to persist and the mean duration of persistent IMI seemed to vary between species (Table 2). However, no statistical analysis was carried out to support this, because strain typing should have been performed to confirm persistent infections. For species identification by tDNA-PCR, peaks lower than $50 \%$ of the average peak heights are eliminated in the tDNA-PCR fingerprints (Supré et al., 2009). These eliminated low peaks can be attributed to strain differences or differences between runs. A small preliminary experiment was set up (data not presented), in which Staph. chromogenes isolates causing persistent IMI selected from each of the 3 herds were run in the same tDNA-PCR and capillary electrophoresis run to look at strain differences. When analyzing the tDNAPCR fingerprints, all peaks were taken into account for that purpose, and most of the epidemiologically related isolates had rather comparable genotypes. The literature documents that the majority of persistent Staph. chromogenes IMI were caused by the same strain per quarter (Taponen et al., 2007; Gillespie et al., 2009, Rajala-Schultz et al., 2009), although some so-called persistent Staph. chromogenes infections might rather be re-infections than persistent infections (Gillespie et al., 2009). Interestingly, $C$. bovis was able to persist for extended time periods as well, indicating that this bacterium can also efficiently escape from host immunity. Still, C. bovis has always been regarded as a true minor pathogen and was for that reason included in this study as a reference. This points out that persistency, by itself, should not be considered as the sole indicator for pathogenic potential of an udder pathogen. Bacteria that can cause persistent infections, but that are harmless to the bovine udder, have a neglectable importance. Because persistency was not confirmed based on an evaluated strain-typing technique in our study, our persistence data should be interpreted with care. For that reason, statistical analysis was also not used to substantiate differences between species.

We were not able to show a significant effect of the persistency status of all IMI or of IMI caused by certain pathogens on qSCC, which might be caused by a lack of power as a tendency was present. It looked as if quarters with a persistent Staph. aureus IMI had a higher qSCC than did transiently Staph. Aureus-infected quarters. This was not the case for $C$. bovis IMI or for IMI caused by the important CNS species (Staph. chromogenes, Staph. simulans, or Staph. xylosus), for which no difference was noticed in the qSCC between transiently and persistently infected quarters (data not shown).

In conclusion, the data from this study confirm that CNS, as a group, should be considered as minor pathogens, because they were not involved in CM and because their overall effect on qSCC was limited. However, effect on qSCC is species-specific and species distribution is herd-specific, showing the need for accurate species identification. Special attention should be given to Staph. chromogenes, Staph. simulans, and Staph. xylosus because of their substantial effect on 
SCC, similar to that of Staph. aureus. These species can be highly prevalent and may cause persistent infections. More research is necessary to explain herd dependency and to examine cow- and quarter-level risk factors for (transient and persistent) IMI with different CNS species, eventually resulting in cost-benefit analyses for management changes and, if needed, treatment recommendations.

\section{ACKNOWLEDGMENTS}

This study was supported by the Institute for the Promotion of Innovation through Science and Technology in Flanders (IWT-Vlaanderen, grant $\mathrm{n}^{\circ}$ 61459). The farmers that cooperated in this work are gratefully acknowledged. The authors also thank Linda De Weert (Milk Control Centre Flanders, Lier, Belgium) for her excellent laboratory assistance.

\section{REFERENCES}

Baele, M., P. Baele, M. Vaneechoutte, V. Storms, P. Butaye, L. A. Devriese, G. Verschraegen, M. Gillis, and F. Haesebrouck. 2000. Application of tRNA intergenic spacer PCR for identification of Enterococcus species. J. Clin. Microbiol. 38:4201-4207.

Barkema, H. W., Y. H. Schukken, T. J. G. M. Lam, M. L. Beiboer, H. Wilmink, G. Benedictus, and A. Brand. 1998. Incidence of clinical mastitis in dairy herds grouped in three categories by bulk milk somatic cell counts. J. Dairy Sci. 81:411-419.

Chaffer, M., G. Leitner, M. Winkler, A. Glickman, O. Krifucks, E. Ezra, and A. Saran. 1999. Coagulase-negative staphylococci and mammary gland infections in cows. J. Vet. Med. 46:707-712.

De Vliegher, S., H. Laevens, L. A. Devriese, G. Opsomer, J. L. Leroy, H. W. Barkema, and A. de Kruif. 2003. Prepartum teat apex colonization with Staphylococcus chromogenes in dairy heifers is associated with low somatic cell count in early lactation. Vet. Microbiol. 92:245-252.

De Vliegher, S., G. Opsomer, A. Vanrolleghem, O. Sampimon, J. Sol, H. W. Barkema, F. Haesebroeck, and A. de Kruif. 2004. In vitro growth inhibition of major mastitis pathogens by Staphylococcus chromogenes originating from teat apices of dairy heifers. Vet. Microbiol. 101:215-221.

Gillespie, B. E., S. I. Headrick, S. Boonyayatra, and S. P. Oliver. 2009 Prevalence and persistence of coagulase-negative Staphylococcus species in three dairy research herds. Vet. Microbiol. 134:65-72.

Hogan, J. S., R. N. Gonzáles, R. J. Harmon, S. C. Nickerson, S. P. Oliver, J. W. Pankey, and K. L. Smith. 1999. Laboratory Handbook on Bovine Mastitis. Rev. ed. National Mastitis Council, Madison, WI.

Hogan, J. S., K. L. Smith, D. A. Todhunter, and P. S. Schoenberger. 1988. Rate of environmental mastitis in quarters infected with Corynebacterium bovis and Staphylococcus species. J. Dairy Sci. $71: 2520-2525$.

Hyvönen, P., S. Käyhkö, S. Taponen, A. von Wright, and S. Pyörälä. 2009. Effect of bovine lactoferrin on the internalization of coagulase-negative staphylococci into bovine mammary epithelial cells under in vitro conditions. J. Dairy Res. 76:144-151.

Kuroishi, T., K. Komine, K. Kai, M. Itagaki, J. Kobayashi, M. Ohta, S. Kamata, and K. Kumagai. 2003. Concentrations and specific antibodies to staphylococcal enterotoxin-C and toxic shock syndrome toxin- 1 in bovine mammary gland secretions, and inflammatory response to the intramammary inoculation of these toxins. J. Vet. Med. Sci. 65:899-906.
Lam, T. J., Y. H. Schukken, J. H. van Vliet, F. J. Grommers, M. J. Tielen, and A. Brand. 1997. Effect of natural infection with minor pathogens on susceptibility to natural infection with major pathogens in the bovine mammary gland. Am. J. Vet. Res. 58:17-22.

Lipman, L. J. A., A. de Nijs, T. J. G. M. Lam, J. A. Rost, L. van Dijk, Y. H. Schukken, and W. Gaastra. 1996. Genotyping by PCR, of Staphylococcus aureus strains, isolated from mammary glands of cows. Vet. Microbiol. 48:51-55.

Matos, J. S., D. White, R. J. Harmon, and B. E. Langlois. 1991. Isolation of Staphylococcus aureus from sites other than the lactating mammary gland. J. Dairy Sci. 74:1544-1549.

Piepers, S., L. De Meulemeester, A. de Kruif, G. Opsomer, H. W. Barkema, and S. De Vliegher. 2007. Prevalence and distribution of mastitis pathogens in subclinically infected dairy cows in Flanders, Belgium. J. Dairy Res. 74:478-483.

Rajala-Schultz, P. J., K. L. Smith, J. S. Hogan, and B. C. Love. 2004 Antimicrobial susceptibility of mastitis pathogens from first lactation and older cows. Vet. Microbiol. 102:33-42.

Rajala-Schultz, P. J., A. H. Torres, F. J. DeGraves, W. A. Gebreyes, and P. Patchanee. 2009. Antimicrobial resistance and genotypic characterization of coagulase-negative staphylococci over the dry period. Vet. Microbiol. 134:55-64.

Sampimon, O. C., H. W. Barkema, I. M. G. A. Berends, J. Sol, and T. J. G. M. Lam. 2009a. Prevalence and herd-level risk factors for intramammary infection with coagulase-negative staphylococci in Dutch dairy herds. Vet. Microbiol. 134:37-44.

Sampimon, O.. B. H. P. van den Borne, I. M. G. A. Santman-Berends, H. W. Barkema, and T. J. G. M. Lam. 2010. The effect of coagulase-negative staphylococci on somatic cell count in Dutch dairy herds. J. Dairy Res. 77:318-324.

Sampimon, O. C., R. N. Zadoks, S. De Vliegher, K. Supré, F. Haesebrouck, H. W. Barkema, J. Sol, and T. J. G. M. Lam. 2009b. Performance of API Staph ID 32 and Staph-Zym for identification of coagulase-negative staphylococci isolated from bovine milk samples. Vet. Microbiol. 136:300-305.

Santos, O. C. S., E. M. Barros, M. A. V. P. Brito, M. C. F. Bastos, K. R. N. dos Santos, and M. Giambiagi-deMarval. 2008. Identification of coagulase-negative staphylococci from bovine mastitis using RFLP-PCR of the groEL gene. Vet. Microbiol. 130:134-140.

Schukken, Y. H., R. N. González, L. L. Tikofsky, H. F. Schulte, G. C. Santisteban, F. L. Welcome, G. J. Bennett, M. J. Zurakowski, and R. N. Zadoks. 2009. CNS mastitis: Nothing to worry about? Vet. Microbiol. 134:9-14.

Smith, T. H., L. H. Fox, and J. R. Middleton. 1998. Outbreak of mastitis caused by one strain of Staphylococcus aureus in a closed dairy herd. J. Am. Vet. Med. Assoc. 212:553-556.

Supré, K., S. De Vliegher, I. Cleenwerck, K. Engelbeen, S. Van Trappen, S. Piepers, O. C. Sampimon, R. N. Zadoks, P. De Vos, and F. Haesebrouck. 2010. Staphylococcus devriesei sp. nov., isolated from teat apices and milk of dairy cows. Int. J. Syst. Evol. Microbiol. doi:10.1099/ijs.0.015982-0.

Supré, K., S. De Vliegher, O. C. Sampimon, R. N. Zadoks, M. Vaneechoutte, M. Baele, E. De Graef, S. Piepers, and F. Haesebrouck. 2009. Technical note: Use of transfer RNA-intergenic spacer PCR combined with capillary electrophoresis to identify coagulase-negative Staphylococcus species originating from bovine milk and teat apices. J. Dairy Sci. 92:3204-3210.

Taponen, S., J. Björkroth, and S. Pyörälä. 2008. Coagulase-negative staphylococci isolated from bovine extramammary sites and intramammary infections in a single dairy herd. J. Dairy Res. 75:422429

Taponen, S., J. Koort, J. Björkroth, H. Saloniemi, and S. Pyörälä. 2007. Bovine intramammary infections caused by coagulase-negative staphylococci may persist throughout lactation according to amplified fragment length polymorphism-based analysis. J. Dairy Sci. 90:3301-3307.

Taponen, S., H. Simojoki, M. Haveri, H. D. Larsen, and S. Pyörälä. 2006. Clinical characteristics and persistence of bovine mastitis caused by different species of coagulase-negative staphylococci identified with API or AFLP. Vet. Microbiol. 115:199-207. 
Tenhagen, B.-A., G. Köster, J. Wallmann, and W. Heuwieser. 2006. Prevalence of mastitis pathogens and their resistance against antimicrobial agents in dairy cows in Brandenburg, Germany. J. Dairy Sci. 89:2542-2551.

Thorberg, B.-M., M.-L. Danielsson-Tham, U. Emanuelson, and K. Persson Waller. 2009. Bovine subclinical mastitis caused by different types of coagulase-negative staphylococci. J. Dairy Sci. 92:4962-4970.

Waage, S., T. Mørk, A. Røros, D. Aasland, A. Hunshamar, and S. A Ødegaard. 1999. Bacteria associated with clinical mastitis in dairy heifers. J. Dairy Sci. 82:712-719.
Zadoks, R. N., H. G. Allore, H. W. Barkema, O. C. Sampimon, G. J Wellenberg, Y. T. Gröhn, and Y. H. Schukken. 2001. Cow- and quarter-level risk factors for Streptococcus uberis and Staphylococcus aureus mastitis. J. Dairy Sci. 84:2649-2663.

Zadoks, R. N., and J. L. Watts. 2009. Species identification of coagulase-negative staphylococci: Genotyping is superior to phenotyping. Vet. Microbiol. 134:20-28.

Zhang, S., and C. W. Maddox. 2000. Cytotoxic activity of coagulase-negative staphylococci in bovine mastitis. Infect. Immun. 68:1102-1108. 